\title{
Orchid exploration in Mount Bintan Besar Protected Forest, Bintan Island, Riau Islands Province, Sumatra, Indonesia
}

\author{
DWI MURTI PUSPITANINGTYAS \\ Center for Plant Conservation Botanic Gardens (Bogor Botanic Gardens), Indonesian Institute of Sciences. Jl. Ir. H. Juanda 13, Bogor 16122 West Java, \\ Indonesia. Tel./fax.: +62-251-8311362, 8336871, email: puspitakrb@gmail.com
}

Manuscript received: 1 February 2018. Revision accepted: 17 May 2018.

\begin{abstract}
Puspitaningtyas DM. 2018. Orchid exploration in Mount Bintan Besar Protected Forest, Bintan Island, Riau Islands Province, Sumatra, Indonesia. Biodiversitas 19: 1081-1088. Sumatra is one of the main islands in Indonesia. The biodiversity is higher than Java, but still below compare to Borneo and New Guinea. About 1,118 species of orchids are found growing in Sumatra, which $41 \%$ of these are endemic to Sumatra. The exploration activities were conducted at Gunung Bintan Besar Protected Forest, Bintan island-Sumatra. Orchid exploration was conducted in this area to collect living plants for ex situ conservation purpose. Orchid inventory to record orchid diversity in this area, based on plant collection by purposive random sampling. The results of the study recorded approximately 23 orchid collection numbers found in that area. These were representative of 15 genera and consist of 14 species of epiphyte orchids and 9 species of terrestrial orchids. Most orchids found in this area are lowland orchid which are very common in Sumatra. Dendrobium metachilinum Rchb.f., Dendrobium leonis (Lindl.) Rchb.f. and Plocoglottis lowii Rchb.f. are unique orchids species found on this island. $\square$
\end{abstract}

Keywords: Bintan Island, exploration, inventory, orchid

\section{INTRODUCTION}

One-third of 7,500 plant species found in Peninsular Malaysia region was recorded as the potential plants which have economic value, such as woody plants, medicinal plant, spice and herbal plants, ornamental plants etc., Most of which are occurred in Sumatra (Burkill 1966). There is a relationship of the geology between Sumatra and mainland Southeast Asia in the past, therefore there is a phenomenon that some species of flora and fauna in Sumatra have similarities to those in mainland Southeast Asia.

Sumatra is an island with a high level of biodiversity compared to Java, but its level is still below Borneo and New Guinea (Meijer 1981). The location of the island of Sumatra is very strategic, has a tropical climate with warm temperature throughout the year, as well as relatively constant rainfall, are the factors that create ideal conditions for the growth of flora. A diverse number of plant species is reflectance of how rich biological resources in Sumatra and most of them have high economic value.

Indonesia has been recognized as one of megabiodiversity country after Brazil and Congo (Butler 2016). Indonesia archipelago consists of more than 17,000 small islands with enormous genetic plant's diversity, with many different types of habitats and an extremely complicated geological history (Bruyn et al. 2014). Some of them are endemic species of the island. Due to limited distribution and the species only found on small islands, causes them vulnerable to extinction. Establishment and development of conservation area such as botanic garden is one effort to reduce the degradation of plant diversity in small islands. $\square$

Nowadays exploration activities, especially orchids are considered very important, because many orchid's natural habitats are degraded. Destruction of the orchid's natural habitat has increased sharply and has been accelerated by human activities such as housing, industry, plantation and so on. WCMC (1995) states that 203 orchids species are the highest threatened species (39\%) compared to other threatened species of Indonesia. It is even possible when a lot of orchids are extinct before they have been described or documented. In Java, many forest areas have been converted into settlements, housing or plantations so that the orchid population in the wild is threatened. In addition, wild orchid traders illegally harvest in nature, this also triggers the decline in the populations of wild orchid in nature without any effort to cultivate the orchids. Furthermore, natural disasters also become one of causes the declining population in nature. Comber (1990) reported that in Java there are approximately 731 orchids species, which are estimated 248 species of endemic orchids in West Java, 16 species endemic orchid in Central Java and 49 species endemic orchid in East Java. While in Sumatra there are approximately identified 1118 orchid species, $41 \%$ of which are endemic orchid in Sumatra (Comber 2001).

In the effort to fulfill its mission of ex situ conservation, botanic gardens in Indonesia carry out exploration activities and plants inventory to study the plant diversity. One of the points interest in Bogor Botanic Garden is the research on orchid. WCMC (1995) states that 203 orchids species are the highest threatened species (39\%) compared to other threatened species of Indonesia. The aim of the research here was to inventory orchid diversity in Mount Bintan Besar and also to enrich the orchid collection of Bogor Botanic Gardens and Batam Botanic Gardens. 


\section{MATERIALS AND METHODS}

The research was conducted in the area of Mount Bintan Besar Protected Forest, located in Kampung Bekapur, Bintan Buyu Village, Bintan Bay Sub-district, Bintan District, Riau Islands Province, Indonesia, from April 19 to May 18, 2015.

The objective was to observe orchid diversity in Mount Bintan Besar. The exploration activity was based on plant collection by purposive random sampling (Partomihardjo and Rahajoe 2005). The living material collected was mostly planted out in Bogor Botanic Gardens and Batam Botanic Gardens for ex-situ conservation purposes. For orchids collected not in flower, it is usually only possible for an initial identification to be made to genus level. To identify to species level, it is usually necessary to observe the flower morphology. Identification methods were used by reference to herbarium specimens in the Herbarium Bogoriense and or living collections in the Bogor Botanical Gardens (Hidayat et al. 2017). Literature reviews (Comber 1990, 2001; Seidenfaden and Wood 1992; Gravendeel 2000) were also used to support identification. Valid names were attributed based on the current listings in "The Plant List, A Working List of All Plant Species" (www.theplantlist.org). Plants were only sampled and collected for those species that were abundant in the field, so as to support in situ conservation of the species. Some rare species were not sampled and were only recorded or photographed for documentation.

\section{RESULTS AND DISCUSSION}

Bintan Island has only one mountain namely Gunung Bintan Besar (Mount Bintan Besar). The mountain is located in the middle of Bintan Island and is about $55 \mathrm{~km}$ from the city of Tanjung Pinang (the capital city of Riau Islands Province). It is a protected forest area of tropical rainforest. Topography is hilly and the slopes are ramp to steep. Mount Bintan Besar Protected Forest has an altitude of 11-400 $\mathrm{m}$ above sea level. It is located in Kampung Bekapur, Bintan Buyu Village, Bintan Bay District, Bintan District, Riau Islands. Mount Bintan is a catchment area and becomes a destination place for ecotourism. The habitat in Mount Bintan Besar is described as primary forest and secondary forest which disturbed by human activities such as forest burning for planting horticulture crops. Primary data is obtained through direct survey to the field during exploration activities. Primary data of environment was recorded using instrument thermohygrometer, altimeter, and soil pH-tester tools. Exploration in this habitat was carried out at an altitude between 5-213 $\mathrm{m}$ above sea level (asl.).; temperature was about $24-31^{\circ} \mathrm{C}$; the degree of soil acidity (soil $\mathrm{pH}$ ) was 4.6-6.8 and humidity $(\mathrm{RH})$ was $78-83 \%$.
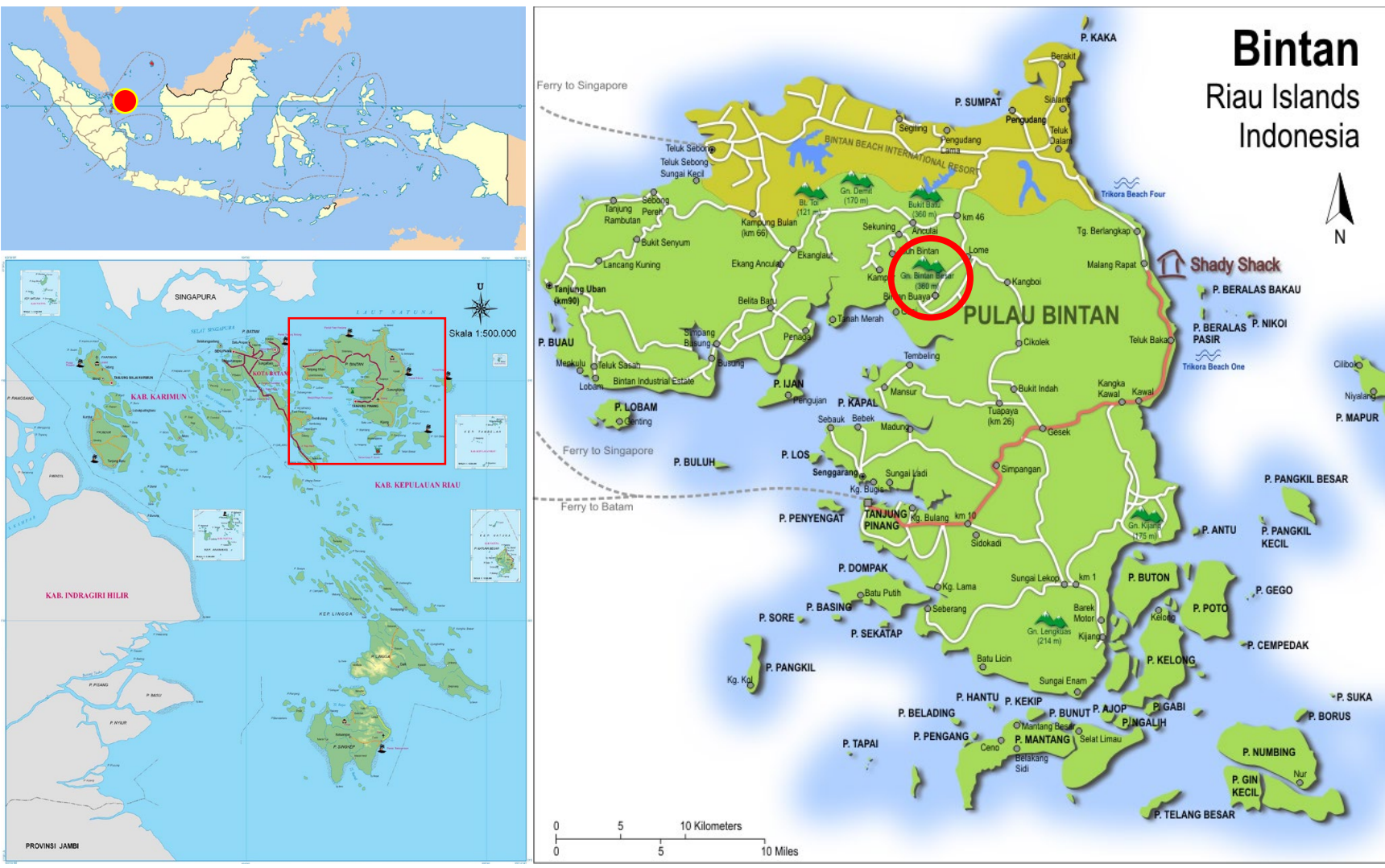

Figure 1. The location of Mount Bintan Besar (red circle) in Bintan Island, Riau Islands, Indonesia 


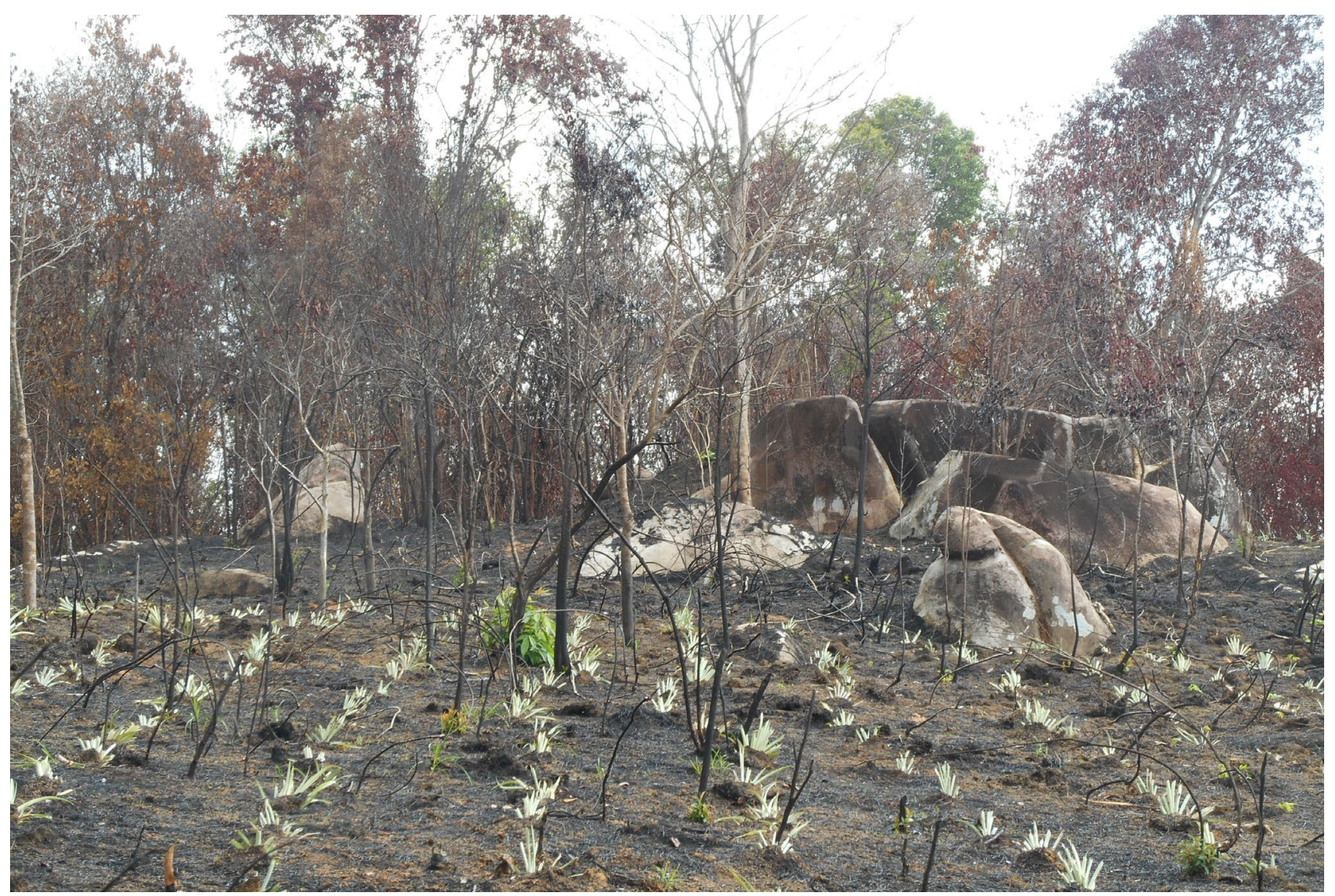

Figure 2. Forest burning for planting horticulture crops around Mount Bintan Besar in Bintan Island, Riau Islands, Indonesia

Table 1. The list of orchid species found in Mount Bintan Besar Protected Forest, Bintan Island, Riau Islands Province, Sumatra, Indonesia

\section{Orchid species}

\section{Terrestrial orchid}

Arachnis sp.

Bromheadia finlaysoniana (Lindl.) Miq.

Corymborkis veratrifolia (Reinw.) Blume

Neuwiedia zollingeri Rchb.f. var. zollingeri

Plocoglottis lowii Rchb.f.

Plocoglottis plicata (Roxb.) Ormerod

Spathoglottis plicata Blume

Thrixspermum amplexicaule (Blume) Rchb.f.

Tropidia curculigoides Lindl.

\section{Epiphyte orchid}

Acriopsis liliifolia (J.Koenig) Seidenf.

Agrostophyllum stipulatum (Griff.) Schltr.

Appendicula anceps Blume

Bulbophyllum sp.

Bulbophyllum sp

Bulbophyllum sp.

Bulbophyllum sp.

Bulbophyllum vaginatum (Lindl.) Rchb.f.

Cymbidium finlaysonianum Lindl.

Dendrobium crumenatum Sw.

Dendrobium leonis (Lindl.) Rchb.f.

Dendrobium metachilinum Rchb.f.

Dendrobium salaccense (Blume) Lindl.

Polystachya concreta (Jacq.) Garay \& H.R.Sweet
Sumatra Island is one of the 6th largest islands in the world. Comber (2001) has identified 1118 species of orchids found growing in Sumatra, possibly there are still $10 \%$ of other orchid species that have not been identified. About $41 \%$ are expressed as endemic orchids of Sumatra. The orchids that are inventoried in Bintan Besar Protected Forest area are very low in diversity, only 23 species were found in this area, compared to the diversity of orchids found in Sumatra that about 1118 species (Comber 2001).. $\square$

Generally, the orchids were not found in flowering condition, so species names could not be precisely identified. Approximately $10 \%$ are found in flowering conditions. Based on the results of exploration activities in Mount Bintan Besar Protected Forest Area, we obtained 26 numbers of orchid collections. After blooming, several numbers of orchid collection produce same flowers. Hence our exploration of orchids resulting in 23 species, 15 genera, 238 specimens. It is about $2.06 \%$ of all orchids in Sumatra. This orchid grows at an altitude range of 11-161 $\mathrm{m}$ asl., 14 species of epiphytic orchids and 9 terrestrial orchid species (Table 1.)

Comber (1990) reported that there are approximately 731 species of orchids in Java, and orchid species at high altitude range between 500-1,500 m asl. are more diverse compared to the lower altitude. In Meru Betiri National Park with an altitude less than $100 \mathrm{~m}$ asl, only \pm 25 orchids species found (Puspitaningtyas 2007). Bali has more 
similar orchid with Java rather than to Lesser Sunda Island (Comber 1990; Schuiteman 1999). Furthermore, Schuiteman (1999) stated that not less than $70 \%$ of all orchids known from the Lesser Sunda Islands occur in Java, it means that Lesser Sunda has poor endemic orchid (about 30\%). Schuiteman et al. (2008) mentioned that about 200 orchids species in 72 genera occur in Lesser Sunda Island and 66 species of which occur in East Timor (Silveira et al. 2008). Sulistiarini et al. (2016) have found 20 orchids species in Mount Mesehe and Mount Merbuk in Bali with an altitude range between 200-1.600 m asl. While Girmansyah et al. (2013) have listed 146 orchids species in Bali.

The richness species that occupies in Borneo is the orchid, (Lamb 1991) mentions that there are approximately 2,500-3,000 species (approximately $10 \%$ of the total number of orchids in the world). Of this $30-40 \%$ of the species are endemic orchids to Borneo. Wood and Cribb (1994) mentions more than 1,400 orchid species occur in the Island.

A preliminary catalog on the inventory of orchids in Sulawesi and Maluku, a total of 820 species were recorded of which $60 \%$ (548 species) are found in Sulawesi and 369 species are found in Maluku (Thomas and Schuiteman 2002). Some orchid species which are found in Bintan Besar Protected Forest area will be described in this paper.

\section{Terrestrial orchids}

Arachnis sp.

There were about 9 terrestrial orchid species found in this area. Arachnis sp. has been found in this area. It grows on rock cliffs of the roadside under the full sunlight, as lithophyte or semi-terrestrial orchids. However, it has been not identified to the species level, because it has not flowered yet. It is a new collection for Bogor and Batam Botanic Gardens (BG). While Bromheadia finlaysoniana and Spathoglottis plicata are also found in the open area as terrestrial, on red clay soil not on rocky hill.

\section{Bromheadia finlaysoniana (Lindl.) Miq.}

This terrestrial orchid is about $70-200 \mathrm{~cm}$ height, sympodial with stiff leaves. The leaves are ellipticlanceolate, the tip is bilobed, asymmetrically, alternate, the size is about $10-15 \times 2-3 \mathrm{~cm}$. Inflorescence arises from the upper trunk segment, $15 \mathrm{~cm}$ long, rarely branching, supporting 1-2 flower buds that bloom simultaneously. The flowers are white with yellow interiors and red variations on the lips. Flower is wide open, 5-6 cm in diameter, only a half day blooming.

Bromheadia finlaysoniana (Lindl.) Miq. is a new collection for Batam BG, but recollection for Bogor BG. This terrestrial species is more common growing in poor nutrients, on red clay soil or on the open bush, under full sunlight and it needs moderate rainfall. Generally grown in the lowlands at 0-200 meters altitude, but sometimes can be found at an altitude of more than $1,100 \mathrm{~m}$ asl. Its distribution is wide spreads ranging from Burma, Thailand, Laos, Cambodia, Vietnam, Peninsular Malaysia, Sumatra, Borneo, New Guinea to Australia (Comber 2001).

\section{Corymborkis veratrifolia (Reinw.) Blume}

Corymborkis veratrifolia is a tough, evergreen, terrestrial orchid without underground storage. It has a hard, erect, unbranched and leafy stem, growing to $1.5-2 \mathrm{~m}$ tall. Leaves are lanceolate, plicate and tough, with pointed leaf tip; sessile, leaf position alternately around the stem, about $35 \times 10 \mathrm{~cm}$. The inflorescence is axillary, arranged in panicles, branched, each branch bears three pure white or greenish-white flowers. Sepals are lanceolate, acute, spreading; petals oblong, spreading wider, apices curled back; lip is trilobed, entire, $3 \mathrm{~cm}$ long and $1.5 \mathrm{~cm}$ broad, convex, the margins undulate (Comber 1990). This orchid love growing in shady and moist habitats, especially in rich humus soil. It mostly grows at an altitude of 0-2.000 m asl. The distribution is from India, Southeast Asia to some parts of the Pacific islands. In Indonesia, it spread from Sumatra, Java, Borneo to Sulawesi.

Plocoglottis lowii Rchb.f. and Plocoglottis plicata (Roxb.) Ormerod although both two species are not yet flowering but both are easily distinguished from the color of the leaves, $P$. lowii has a dark green leaf color, while $P$. plicata has green leaf color. Meanwhile, Tropidia curculigoides Lindl. is recorded as a new collection for Batam BG, but for Bogor BG became a recollection from Sumatra because the existing collection from Java and Sumatra has died. $\square$

\section{Plocoglottis lowii Rchb.f.}

Plocoglottis lowii is a terrestrial orchid with conical, olive, purple pseudobulbs. Pseudobulb about $7-8 \mathrm{~cm}$ tall by $1.5-2 \mathrm{~cm}$ thick at the base, covered with sheaths when young, carrying a single leaf. Leaf is solitary lanceolate, acute, plicate, glabrous, up to $28-30 \mathrm{~cm}$ long by $8-9 \mathrm{~cm}$ wide, petiole $4-5 \mathrm{~cm}$ long, shiny greenish purple above and deep purple beneath. Inflorescence is up to $70-100 \mathrm{~cm}$ tall, erect, pubescent, with many flowers but only one flower opening at a time. Flower is $3 \mathrm{~cm}$ in diameter, dorsal sepal and petals are narrow, measured about $1.3-1.5 \mathrm{~cm}$ long and 3-5 mm wide, spreading, tip pointed, pale yellow. Lateral sepals are red with yellow patch a half, curly and recurved inside. Lip rectangular to square, $6 \mathrm{~mm}$ long by $7 \mathrm{~mm}$ wide, thick, fleshy and red, with narrow tip and bent down. These flowers have a moveable lip that triggers and shuts tight when something touches it.

It is found in Thailand, Peninsular Malaysia, Borneo, Sumatra, in lowland and hill forests at elevations of sealevel $(0 \mathrm{~m})$ to $1,000 \mathrm{~m}$ (Seidenfaden and Wood 1992; Teoh 2016).

\section{Plocoglottis plicata (Roxb.) Ormerod}

Plocoglottis plicata is a terrestrial orchid, its pseudobulbs are succulent, elongated, about $9 \times 1 \mathrm{~cm}$, closed together, supporting one leaf. Leaf is elliptic to oval, on a stouts $7-15 \mathrm{~cm}$ long petiole, plicate, measuring $20-25 \mathrm{~cm}$ long by $9-11 \mathrm{~cm}$ wide. Inflorescence one-two to a pseudobulb, up to $45 \mathrm{~cm}$ long including $30 \mathrm{~cm}$ red peduncle, rachis which is also red and short-hairy, bearing 10-15 well spaced-out flowers but only 2-4 buds that bloom together. The flowers are small, $\pm 3 \mathrm{~cm}$ in diameter, the petals colored pale yellow heavily spotted with reddish- 
brown around the base. The flower petals $\pm 2.5 \mathrm{~cm} \times 9 \mathrm{~mm}$, the dorsal sepal curve forward and the lateral sepals turned downwards, spreading out apically. Petals much narrower and stretching upwards, not incurved. Lip is yellow, with two red blotches near the base, more or less square, the apex turned downwards. (Comber 1990; Comber 2001).

It is found in Java, Borneo, Sumatra, Sulawesi, Moluccas, Peninsular Malaysia and the Philippines. It is growing in lowland to highland, in mixed montane rainforests, in deep shade, in alluvial soils with sandstone or limestone, at elevations very close to sea level to 1,200 $\mathrm{m}$ asl.

\section{Tropidia curculigoides Lindl.}

Tropidia curculigoides is a terrestrial orchid with an often branched, woody stem and basally clasping. The leaves are thin but tough, plicate, narrowly lanceolate with pointed tip. The leaves are held in a spiral around the stem. Inflorescences both lateral and terminal, peduncle short, \pm 1.5-2 cm, support 6-10 flowers. The flowers are creamywhite, the tips of petals and sepals are green, very small flower size, not fully opening, $\pm 1 \mathrm{~cm}$ broad. Dorsal sepals long-oblong, concave apical half, $1 \mathrm{~cm}$ long by $3.5 \mathrm{~mm}$ broad; lateral sepals more acute, $1.37 \mathrm{~cm}$ long by $3.5 \mathrm{~mm}$ broad. Petals lanceolate, more obtuse, very concave, $1 \mathrm{~cm}$ long by $3.5 \mathrm{~mm}$ broad. This orchid can be found in Assam, Bangladesh, eastern Himalayas, Sikkim, Lower India, Andaman Islands, Myanmar, Thailand, Laos, Cambodia, Yunnan China, Hong Kong, Vietnam, Malaysia, Borneo, Java, Lesser Sunda Islands, Sumatra, Sulawesi, New Guinea and New Caledonia at elevations of up to $1,300 \mathrm{~m}$ asl. (Comber 1990; Comber 2001).

\section{Spathoglottis plicata Blume}

Spathoglottis plicata is a very common terrestrial orchid in tropical areas. Pseudo-bulb is ovoid, underground, covered with leaf sheaths, each carrying 4-7 leaves. Leaves narrowly lanceolate, up to $100 \times 6 \mathrm{~cm}$. Inflorescence is longer than the leaves, can reach 1-2 m, supporting about 10-30 flowers. The colors are bright mauve, pale pink or pure white. The flowers are bloom simultaneously with usually 5 or 6 open at any one time, fully open, $3.5-4 \mathrm{~cm}$ in diameter. Sepals broadly lanceolate, measuring $2 \times 1.2 \mathrm{~cm}$, petals ovate, broader than the sepals, $\pm 2 \times 1.5 \mathrm{~cm}$. Lip is trilobes, the mid-lobe is spathulate like a spoon, pointed at the base and widened at the ends. This orchid grows at an altitude of 0-1,600 m asl. Usually found in grasslands or on the banks of rivers, in open area where there is no competition with tree plants. It is widespread throughout Bangladesh, East Himalayas, Assam, India, Sri Lanka, the Andaman Islands, South-East Asia to New Guinea, Australia and the Pacific Islands (Comber 2001, Seidenfaden and Wood 1992).

\section{Neuwiedia zollingeri Rchb.f.}

Neuwiedia zollingeri is a terrestrial orchid without underground bulb. Leaves are arising from the basal part of the stem, placed close together, lanceolate, plicate, acuminate, the lowest ones largest, measured about $50 \times 7$ $\mathrm{cm}$ including $6 \mathrm{~cm}$ petiole, upper ones much smaller, without petioles, sheathing the peduncle. Inflorescence lengthening to $10 \mathrm{~cm}$, bearing up to 80 flowers. Flowers are golden yellow, not opening widely, with narrowly lanceolate, acuminate floral bracts. Sepals and petals lanceolate, $17 \times 3.5 \mathrm{~mm}$; petals wider, $\pm 6 \mathrm{~mm}$ broad, the lip oblong, all the tepals end in a cusp. It is found in Java and Sumatra in hill forests at elevations around 700 to $1,300 \mathrm{~m}$ asl. (Comber 1990).

\section{Thrixspermum amplexicaule (Blume) Rchb.f.}

Thrixspermum amplexicaule is a terrestrial orchid which thrives in poor grassland or on rock under full sun. Monopodial stem can reach 1-2 m tall, bearing leaves along their length, placed about $4 \mathrm{~cm}$ apart alternately. Leaves 3$6 \times 2-2.5 \mathrm{~cm}$, thick fleshy, bases of leaves clasp the stem. The peduncle of inflorescence is very long and stout, up to $26 \mathrm{~cm}$, rachis gradually expanding to more than $10 \mathrm{~cm}$ long. Flowers opening one or two at a time, pale mauve or white, $3.5 \mathrm{~cm}$ broad. Sepals $17 \times 11 \mathrm{~mm}$ and petal shorter less than $15 \mathrm{~mm}$, the pouch lip $6 \mathrm{~mm}$ deep, inside with a small yellow callus and a band of orange hairs below it, the mid lobe white, obtuse and fleshy, the side lobes small and pointed. It is widespread in South East Asia (Comber 1990).

\section{Epiphyte orchid}

Among the epiphyte orchids growing in this area, Bulbophyllum is the common orchid in this place, especially Bulbophyllum vaginatum (Lindl.) Rchb.f. Other common orchids found in this area are: Dendrobium leonis (Lindl.) Rchb.f. and some other Bulbophyllum spp.

Dendrobium leonis (Lindl.) Rchb.f. is a new collection for Batam BG, while Bogor BG already has this collection. Polystachya concreta (Jacq.) Garay \& H.R.Sweet is also a new collection for Batam BG and this species has already existed as Bogor BG's collections which are mainly collected from Java.

\section{Bulbophyllum spp.}

There is 5 number of Bulbophyllum collections found. Those species are epiphytes orchid with creeping sympodial bulb. Only one species of them were flowering, namely Bulbophyllum vaginatum (Lindl.) Rchb.f. However, the others did not bloom, so they cannot be identified for the species and cannot be specifically described. $\square$

\section{Bulbophyllum vaginatum (Lindl.) Rchb.f.}

Bulbophyllum vaginatum is an epiphytes orchid with sympodial bulb, creeping, $5 \mathrm{~cm}$ space between nodes. Bulb ovoid, slightly rectangular when growing, size $2 \times 1 \mathrm{~cm}$. The leaves are single per bulb, elliptic-oblong, the tip obtuse and slightly bilobed, $12 \times 2.5 \mathrm{~cm}$ in size. Inflorescence arising from the base of bulb, peduncle $9 \mathrm{~cm}$ long, and rachis $1 \mathrm{~cm}$, produces numerous umbel flowers, 12-15 flowers, bloom simultaneously, yellowish white or creamy yellow. Dorsal sepal hood-shaped, margin hairy, pointed tip, $8 \mathrm{~mm}$ long, lateral sepals $6.5 \mathrm{~cm}$ long, united at the base, then spreading to the tip, loose like beard. Petal 
ellipse, margin hairy, $2.5 \mathrm{~mm}$ long. Lips like a tongue, 2 $\mathrm{mm}$ long, dark cream or pale yellow.

This species is commonly found in secondary forests, mangroves, lowland swamp forests at an altitude of 0-600 $\mathrm{m}$ asl. It usually grows on the trunk of a tree forming a large colony. This orchid is widespread in Thailand, Malaysia, Sumatra, Java, and Borneo (Comber 1990; O'Byrne 2001; Seidenfaden and Wood 1992).

\section{Acriopsis liliifolia (Koen.) Ormerod}

This epiphytic orchid has a sympodial habit, with ovoid bulb, supports 2-4 leaves. Leaves are linear, and obtuse on the tip, size is about $28-30 \mathrm{~cm}$ long and $2-2.5 \mathrm{~cm}$ wide. Inflorescence branched; arranged in panicle, $60 \mathrm{~cm}$ long, support many small flowers, $\pm 1-1.25 \mathrm{~cm}$ broad. Petals are white-pale yellow with reddish-brown variations in the middle. Lips stretching wide, white on the base with pinkish in the middle. It is commonly found growing attached to the trunk or branching of trees on the roadside and secondary forest disturbed. It grows well in the lowlands $(0 \mathrm{~m}$ asl. $)$ to the mountain areas $(1,100 \mathrm{~m}$ asl. $)$. Its spread includes Southeast Asia, Papua New Guinea, Australia and the Solomon Islands (Comber 1990; O'Byrne 2001).

\section{Agrostophyllum stipulatum (Griff.) Schltr.}

This epiphytic orchid has cluster stems which emerge from their rhizomes, the length can reach $100 \mathrm{~cm}$. Leaves almost overlap, obtuse and bi-lobe at the tip. The inflorescence support one or two flowers in each set, which are fully open, $11 \mathrm{~mm}$ wide, pale yellow. The petals are slightly oval-shaped, measuring $5 \mathrm{~mm}$ in length. The sepals are linear-shaped, $1.2 \mathrm{~mm}$ wide. Lip is white with red dots near the base, divided into three lobes, both side lobes widened to the side and the middle lobe protrudes forward. It is commonly found at an altitude of $200-1400 \mathrm{~m}$ asl, it grows on the branch of small tree, formed large clumps. This orchid is widespread in Southeast Asia to the Salomon Islands (Comber 1990, 2001; Seidenfaden and Wood 1992).

\section{Appendicula anceps Blume}

This epiphyte orchid has long stem, up to $\pm 45 \mathrm{~cm}$ long, pendulous. Leaves flat, oblong-lanceolate, tip bilobed, alternate, inter-nodes $2-3 \mathrm{~cm}$. Inflorescence both lateral and terminal, hanging down, branched, gradually elongated up to $4 \mathrm{~cm}$, with 3-4 flowers open at one time, flowers small, $\pm 4 \mathrm{~mm}$ in diameter, sepals $2.5 \times 1.5 \mathrm{~mm}$, petals $2 \times 1 \mathrm{~mm}$, white or pale translucent green, lips white with dark red at the base centre, column and anthers are also dark red in front. It grows in lowland area, moist and mossy forest to mountain forests at an altitude of 400-2,500 meters asl. It spreads to Thailand, Peninsular Malaysia, Philippines, Sumatra, Java, Borneo, Lesser Sunda Island, and Sulawesi (Comber 1990; O'Byrne 2001).

\section{Dendrobium leonis (Lindl.) Reichb.f.}

This epiphyte orchid has a sympodial habit, without bulbs with multiple tufted stems. Stem is $\pm 25 \mathrm{~cm}$ long, supporting many sessile leaves. The leaves are triangle shaped and arranged in alternating rows, thick and fleshy, laterally flattened, the upper leaf surface is smooth and very stiff, $1.5-2 \mathrm{~cm}$ long and $\pm 1 \mathrm{~cm}$ wide. Flowers are emerged at the leafless stem apex and are single-flowered, size is about 1.3 to $2.0 \mathrm{~cm}$ in diameter. Dorsal sepal is $\pm 6-7$ $\mathrm{mm}$ long and $\pm 3 \mathrm{~mm}$ wide, tip pointed, lateral sepals wider and united to form a chin (mentum), petals are lanceolate, \pm $5 \times 3 \mathrm{~mm}$. Lips oblong-oval, tip bi-lobed, recurved towards the apex, warty upper surface, $\pm 1 \mathrm{~cm}$ long and $3-5 \mathrm{~mm}$ wide. The flower tepals are pale green or yellow with the lip being a very pale green and flushed with dark purple. Flowers have sweet, vanilla-like fragrance. It was found growing in lowland forest and epiphytes on the trunk of rubber tree. The wide distribution is ranging from Vietnam, Laos, Cambodia, Thailand, Indochina, Natuna Islands, Peninsular Malaysia, Sumatra and Borneo (Seidenfaden and Wood 1992; Comber 2001; O'Byrne 2001).

\section{Dendrobium metachilinum Rchb.f.}

This epiphyte orchid is growing on the stem of host tree with stout rooting, erect to pendent, clustered, stems are rounded slightly oval and deeply grooved when dry, internodes clear, supporting 11 to 13 leaves which are linear- to narrowly oblong, stiffly spreading, unequally obtusely to acutely bi-lobed, glabrous leaves. The inflorescence emerges axillary from nodes opposite the leaves, arranged in cluster, 2-4 flower buds per segment, blooming simultaneously, flower small, size are about 1$1.25 \mathrm{~cm}$ in diameter, light brown to orange. Sepals are oval shape, the tip is pointed, while petals are lanceolate, flowers bracts are ovate, acute, concave (Seidenfaden and Wood 1992). This species distributed in Thailand and Malaysia, Sumatra, Borneo, and Sarawak. This species is commonly found in lowland forests near streams in the tops of tall trees at elevations of 200 meters asl.

\section{Dendrobium salaccense (Blume) Lindl.}

These orchids are growing epiphytes on the trees or lithophyte on rocks in forests and open places, Stems 50-70 cm long, slender, often pendulous, shiny, woody stems. Leaves linear- narrowed shape, slender, distichous grasslike leaves, measuring $\pm 12 \times 1 \mathrm{~cm}$, obtuse and asymmetric bilobe. Inflorescence is emerging from nodes opposite the leaves, flowers are in a pair of each node. Flowers are pale yellow, Sepals and petals are almost the same shape and size, oval-triangular shape, slightly obtuse on the tip, fully open with size is about $\pm 1-2 \mathrm{~cm}$ in diameter. Lips are not distinctive trilobe, the center is narrowed, the shape of the oblong with a prominent repeat. Bracts are brown, this orchid is found growing in China, Myanmar, Thailand, Malaysia, Laos, Vietnam, Java, Borneo and Sumatra in riparian forests at elevations of 500 to 1,800 meters. It generally grows on the main stem of a tree or branching, likes an open place. Grows at an altitude of 0-1,800 $\mathrm{m}$ asl. The distribution covers the regions of Thailand, Laos, Vietnam, southern China, Peninsular Malaysia, Sumatra, Java, and Borneo (Comber 1990; Seidenfaden and Wood 1992). 
Cymbidium finlaysonianum Lindl.

This epiphytic orchid has a sympodial habit, commonly grow on the branch of the trees. Hidden flat and oval bulb, covered by leaves, supports 4-7 strap-shaped leaves and leathery, emerging erect but later arching as it lengthens, semi terrete $36-85 \mathrm{~cm}$ long and $2.7-6 \mathrm{~cm}$ wide, the leaf tip is unequally bilobed. A pendulous inflorescence is borne from the base of the stem, length $60-120 \mathrm{~cm}$, supporting 726 flower buds. The petals and sepals are spreading, 4-6 cm in diameter, the sepals and petals are yellow with or without dark red streaks running along the middle, softly scented. The lip is three-lobed; the tip of the lip is recurved and white with red markings. The flower column is dark red and curved. It generally is growing on the branching of shady trees, in a rather open place, an altitude of $0-1,200 \mathrm{~m}$ asl. Its distribution is from Vietnam, Cambodia, Thailand, Philippines, Peninsular Malaysia, Sumatra, Java, Borneo and Sulawesi (Comber 1990; Seidenfaden and Wood 1992).
Polystachya concreta (Jacq.) Garay \& H.R.Sweet

It is an epiphyte orchid, with sympodial growth habit, pseudobulb small and closes together, flat oval, about $6 \times 2$ $\mathrm{cm}$, supports 2-6 leaves. Leaves with long sheaths at their base, a lanceolate-oblanceolate shape, acute, the largest ones about $25 \times 5 \mathrm{~cm}$. Inflorescence emerging from the top of pseudo-bulbs, paniculate, the peduncle $4-30 \mathrm{~cm}$ long, supporting several branches of inflorescence (1-4), each branch $(1-2 \mathrm{~cm})$ supports $3-8$ buds so that in one flower there are 15-25 small flowers with $5 \mathrm{~mm}$ broad. Flowers are pale green, yellow or light brown sepals are acute, about $4 \mathrm{~mm}$ long, lateral sepals broader than the dorsal sepals, petals are linear, only $0.75 \mathrm{~mm}$ broad. Lip tri-lobed, the mid-lobe is rounded and recurved, most of the inner surface of the lip is covered with short hairs.

It can grow from lowland near sea level to mountains up to a height of $1,650 \mathrm{~m}$ above sea level. It has a worldwide distribution in moist tropical climates (Comber 1990).

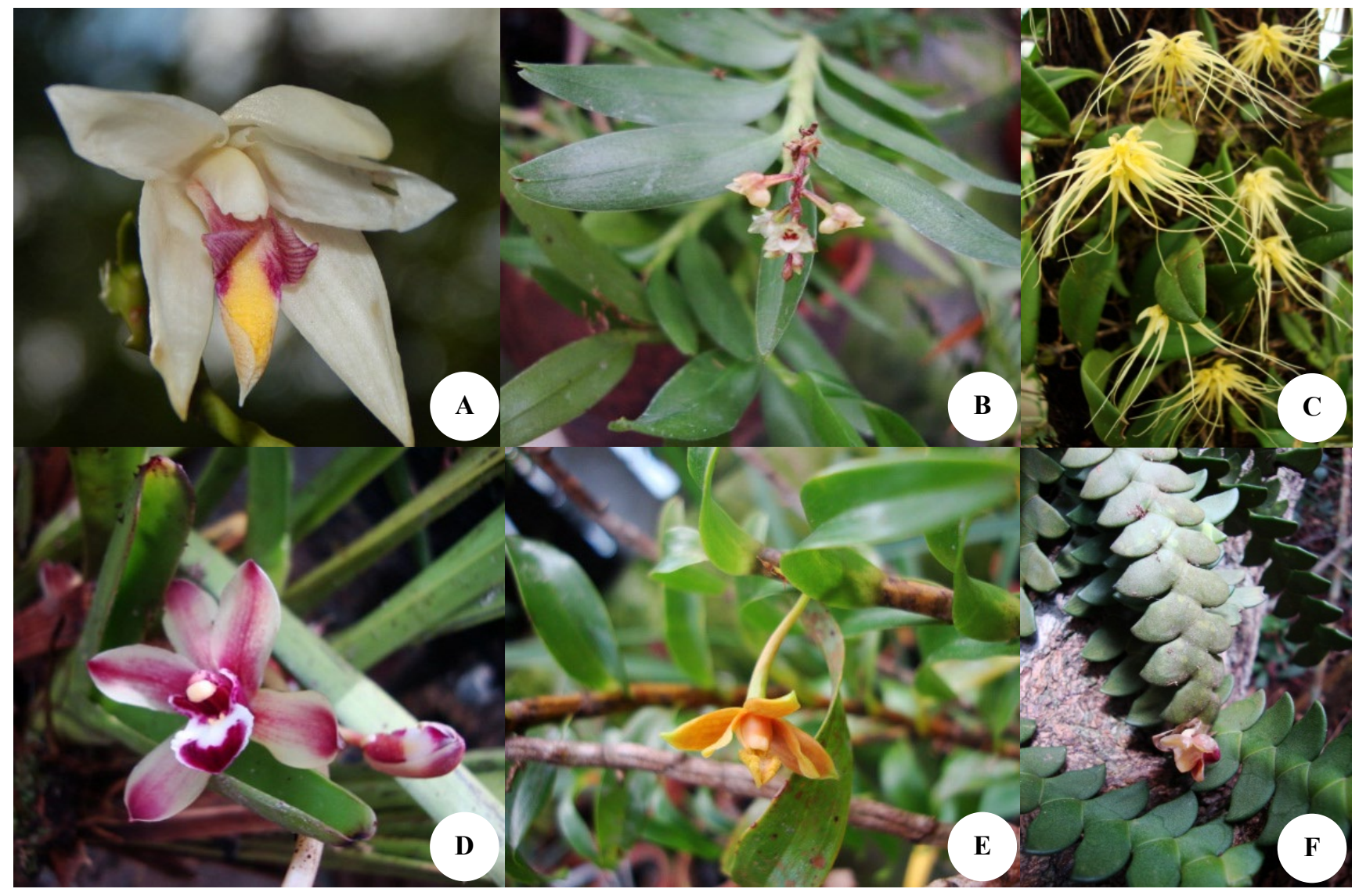

Figure 3. Orchids of Gunung Bintan Besar Protected Forest, Bintan Island, Riau Islands Province, Sumatra, Indonesia. A. Bromheadia finlaysoniana (Lindl.) Miq., B. Appendicula anceps Blume, C. Bulbophyllum vaginatum (Lindl.) Rchb.f., D. Cymbidium finlaysonianum Lindl., E. Dendrobium metachilinum Rchb.f., F. Dendrobium leonis (Lindl.) Rchb.f. 


\section{Dendrobium crumenatum $\mathrm{Sw}$}

It is an epiphyte orchid, with sympodial growth habit, pseudo-bulb is spindle-shaped, swollen basally for a few nodes, ridged, measuring about $4 \times 1 \mathrm{~cm}$, the rest of the stem is stiff and usually erect, the whole stems can be more a meter long, are frequently branched, carrying, 4 to 19, thick, leathery, eventually deciduous leaves. Leaves oblong, lanceolate, tough and leathery, 9x2 cm. Single flower emerges from the leafless nodes of the apical part of the stem, $5 \mathrm{~cm}$ across the sepals, fragrant, flowers are fully open for only one day, partially closing ion the afternoon. Sepals and petals are about $2.5 \times 0.6 \mathrm{~cm}$, acute, sepals are long-triangular and petals lanceolate. Lip is trilobed, sidelobes rounded and erect, the midlobe with irregular margins and a pointed apex with five yellow ribs in the center.

It grows at an altitude of sea level $(0 \mathrm{~m})$ to $500 \mathrm{~m}$ asl., sometimes can be found in up to $1.000 \mathrm{~m}$ asl. It has a widespread distribution in India, China, New Guinea, Christmas Islands and all over South-East Asia including Malaysia, Cambodia, Laos, Vietnam, Lesser Sunda Islands, Moluccas, Sulawesi, Sumatra and the Philippines (Comber 1990).

In conclusion, the results of the study recorded approximately 23 orchid collection numbers found in that area. These were representative of 15 genera, which consisted of 14 species of epiphyte orchids and 9 species of terrestrial orchids. Mostly orchids found in this area are lowland orchid which is very common growing in Sumatra. The unique orchid species found in this island are Dendrobium metachilinum Rchb.f., Dendrobium leonis (Lindl.) Rchb.f and Plocoglottis lowii Rchb.f. Those orchids have to be conserved, both in situ and ex situ conservation. Botanic gardens are one of the solutions to save plants diversity by ex situ conservation. Whereas in situ conservation is primarily rescue the plant habitat in nature. Therefore forest degradation must be prevented to avoid biodiversity loss of flora and fauna, especially in small islands including Batam Island and Bintan Island. Mount Bintan Besar is a protected forest area in which there is a typical ecosystem of tropical rainforest which has to be saved. As a tropical rainforest, Mount Bintan also keeps the biodiversity of flora and fauna. So, it is necessary to keep the remaining forest area as a source of oxygen and other environmental services. $\square$

\section{ACKNOWLEDGEMENTS}

This study was financially supported by the Center for Plant Conservation, Botanic Gardens, LIPI (DIPA 2015). The author would like to thank Dr. Joko R. Witono as a coordinator for the program of Development of Local Botanic Gardens in Indonesia. The author also expresses appreciation to Ahmad Izhar as Head of Agriculture and Forestry Office, Bintan District, Riau Islands Province, who gave permission for doing research in Mount Bintan
Besar. We are grateful to Adek Lanovia, as the head of Batam Botanic Gardens and to Anang Bandono. Finally, the author offers sincere thanks to the exploration team of Mount Bintan Besar (Sri Hartini, Harto, Ponco Yulianto, Mukti Agung, Apep Fry Hidayat, Sumartono).

\section{REFERENCES}

Burkill IH. 1966. A Dictionary of the economic products of the Malay Peninsula. Vol. 1. Ministry of Agriculture and Cooperatives, Governments of Malaysia, Lumpur, Malaysia

Butler RA.. 2016. The Top 10 Most Biodiverse Countries. https://news.mongabay.com/2016/05/top-10-biodiverse-countries. [10 March 2018].

Comber JB. 1990. Orchids of Java. Bentham-Moxon Trust. The Royal Botanic Gardens, Kew, London.

Comber JB. 2001. Orchids of Sumatra. The Royal Botanic Gardens, Kew, London.

de Bruyn M, Stelbrink B, Morley RJ, Hall R, Carvalho GR, Cannon CH, van den Bergh G, Meijaard E, Metcalfe I, Boitani L, Maiorano L, Shoup R, von Rintelen T. 2014. Borneo and Indochina are major evolutionary hotspots for Southeast Asian Biodiversity. Syst Biol 63 (6): 879-901.

Girmansyah D, Santika Y, Retnowati A, Wardani W, Haerida I, Widjaja EA, Van Balgooy MMJ. 2013. Flora of Bali: An Annotated Checklist. Research for Biology, Indonesian Institute of Sciences \& Yayasan Pustaka Obor Indonesia, Jakarta.

Hidayat S, Puspitaningtyas DM, Hartini S, Munawaroh E, Astuti IP, Wawangningrum H. 2017. Flora Exploration: 25 Years of Exploring the Jungle in Indonesia. LIPI Press. Jakarta. [Indonesian]

Lamb A. 1991. Orchids of Sabah and Sarawak. In: Kiew, R. (ed.) The State of Nature Conservation in Malaya. Malayan Nature Soc. \& IDRC, Canada.

Meijer W. 1981. Sumatra as seen by a botanist. Indonesia Circle 25: 1727.

O'Byrne P. 2001. A to Z of South East Asian Orchid Species. Vol 1. Orchid Society of South East Asia, Singapore.

Partomihardjo T, Rahajoe JS. 2005. The data collection of plant ecology in flora biodiversity data collection guidelines In: Rugayah, Widjaja EA, Praptiwi (eds). Research Center for Biology LIPI, Bogor. [Indonesian]

Puspitaningtyas DM. 2007. Inventory of Orchids and the host plant in Meru Betiri National Park - East Java. Biodiversitas 8 (3): 210-214. [Indonesian]

Schuiteman A. 1999. Biogeography of Malesian Orchidaceae. Fl. Males. Bull. 12 (6): 273 - 287.

Schuiteman A. 2008. Orchidaceae: Orchid Genera of the Malesian subregions. Nationaal Herbarium Nederland, Leiden.

Seidenfaden G, Wood JJ. 1992. The Orchids of Peninsular Malaysia and Singapore (A Revision of R.E. Holttum: Orchids of Malaya.). Olsen \& Olsen, Fredensborg, Denmark.

Silveira P, Schuiteman A, Vermeulen JJ, Sousa A, Silva H, Paiva J, de Vogel EF. 2008. Orchids of Timor: Checklist and Jonservation status. Bot J Linn Soc 157: 197 - 215.

Sulistiarini D, Arifisni D, Santika Y. 2016. New Records of Orchidaceae from Bali, Indonesia. Garden's Bull Sing 68 (1): 87-95.

Teoh ES. 2016. Medicinal Orchids of Asia. Springer International, Switzerland.

The Plant List. 2013. The Plant List, A Working List of All Plant Species Version 1.1. Published on the Internet; http://www.theplantlist.org/ [November 1, 2017].

Thomas S, Schuiteman A. 2002. Orchids of Sulawesi and Maluku: a preliminary catalogue. Lindleyana 17 (1):1-72.

WCMC (World Conservation Monitoring Centre). 1995. Indonesian Threatened Plants. Eksplorasi 2 (3): 9.

Wood JJ, Cribb PJ. 1994. A Checklist of the Orchids of Borneo. Royal Botanic Gardens, Kew, UK. $\square$ 